\title{
Student Innovations Related to COVID-19: The International Engineering Design Challenge
}

\author{
Teresa J Kennedy* \\ University of Texas at Tyler, USA \\ *Corresponding author: Teresa J Kennedy, University of Texas at Tyler, USA. \\ To Cite This Article: Teresa J Kennedy. Student Innovations Related to COVID-19: The International Engineering Design Challenge. Am J Biomed \\ Sci \& Res. 2021 - 13(6). AJBSR.MS.ID.001921. DOI: 10.34297/AJBSR.2021.13.001921.
}

Received: 畊 July 27, 2021; Published: 海 August 10, 2021

\begin{abstract}
At the start of 2020, online education experienced a significant increase as educators attempted to mitigate a total stop to learning, fearing their students might lose a critical year of their educational experience. This rise in e-learning, affected by school closures, challenged educators to develop meaningful and timely learning experiences that were accessible and realizable for all their students while at the same time consider diverse digital equity issues affecting full participation. Their drive to increase the learning potentials of their students was a testimony to teachers' commitment to the students they serve. It also highlighted educators' sense of responsibility for the academic and social well-being of their students, many of which were negotiating new learning environments at home. This paper describes student involvement in the COVID-19 Engineering Design Challenge, an international Phenomenon-based Learning (PhBL) project developed to provide students in primary, secondary, and higher education learning environments with an opportunity to think about and reflect on challenges surrounding the COVID-19 pandemic and to develop and share their STEM solutions globally.
\end{abstract}

Keywords: COVID-19, engineering design, Phenomenon-based Learning (PhBL), STEM education

\section{Introduction}

In late December 2019, a new strand of the original SARS virus (SARS-CoV-2) challenged the world [1]. At the writing of this paper, over 4 million people worldwide have reportedly died from COVID-19 [2]. "The sudden and unprecedented shuttering of our nation's school buildings due to the COVID-19 pandemic forced educators to face the most jarring and rapid change of perhaps any profession in history. Within a moment's notice, teachers were asked to leave their classrooms indefinitely and, in many cases, to recreate a learning environment that is 100 percent virtual" [3]. Children around the world spent more time online than ever before. Nearly 1.5 billion children in 173 countries were affected by school closures in 2020 [4].

As schools began to close and classes were quickly moved into online environments during the first few months of 2020, teacher stress elevated, teacher morale dropped significantly, and student engagement decreased [3]. Many teachers and teacher educators rushed to place course content online for their students in response to immediate school closures, while at the same time searching for quality activities for their students to engage in during their rapid and time-consuming transition to online teaching and learning. Teachers wanted their students to engage in more than random activities; they sought relevant and engaging projects focusing on STEM (science, technology, engineering, and mathematics) subjects that would naturally encourage their students to be creative, innovative, and learn more about the situation affecting their communities as well as others across the globe.

The University of Texas at Tyler University Academy (http:// www.uttua.org/), a system of K-12 STEM Lab Schools located on three separate campuses in East Texas (USA), engaged in a COVID-19 Engineering Design Challenge in collaboration with the Texas STEM Coalition (https://txstem.org/) during their transition to an online environment in March 2020. The Challenge followed a Phenomenon-based Learning (PhBL) design. PhBL is an educational 
movement initiated by Finland's education system in 2016 which strives to expand typical Project-based Learning (PBL) and Problembased Learning (PrBL) approaches into learning experiences that immerse students deeper into contextual situations aligned with real-life issues, while also applying knowledge and skills from multiple disciplines. PhBL involves students in inquiry approaches such as the 5E Model (an instructional model encompassing five distinct phases: Engage, Explore, Explain, Elaborate, and Evaluate), and encouraging students to share their innovative ideas and designs widely.

The University Academy is an open-enrollment state-funded charter laboratory school serving students in kindergarten (K) for 5-6-year-olds, through twelfth grade (12) for 17-18-year-olds. The schools' charter is focused on supporting students through STEM pathways that incorporate $21^{\text {st }}$ century skills into all aspects of the curriculum, and the schools' mission aims to develop students who leave school "STEM College and Career Ready" (prepared to enroll in a STEM major at a university). Over the last nine years, University Academy students have been engaged in blended learning through project and problem-based teaching and learning models as well as phenomenon-based learning. UT Tyler preservice teachers are actively involved in the schools and University Academy high school students are engaged in dual credit courses taught by UT Tyler professors. The schools specialize in STEM education and offer students the opportunity to earn a STEM endorsement with an engineering focus, a public service endorsement with a biomedical focus, and a multidisciplinary endorsement. Students often work with community members and with other schools on an international level through inquiry-based projects and share their research reports widely through science fairs and other educational venues.

A detailed description of the COVID-19 Engineering Design Challenge, including a summary of the primary, secondary and higher education projects created through the PhBL project design, follows. The Challenge, initiated in 2020, provided an opportunity for students of all ages to think about and reflect on challenges surrounding the COVID-19 pandemic and to develop and share their STEM solutions globally. Details describing how to join the 2021 COVID-19 Engineering Design Challenge are also included.

\section{What is the COVID-19 Student Engineering Design Challenge?}

The COVID-19 Engineering Design Challenge provides students of all ages (primary, secondary, and higher education) with a platform to identify and design solutions to issues and world-wide problems related to the pandemic. Students are encouraged to identify areas of need, create and design solutions to the challenges they identify, and communicate their ideas/ solutions to their classmates, families, and community members via online environments or following physical distancing guidelines established by their teachers and/or schools.

Participation in the Challenge to date has included simple classroom discussions and brainstorming sessions as well as involved individual and group project development. The "engage" phase of the challenge at the UTT-UA highlighted an engineering innovation developed by a U.S. engineering company working with developers to build coronavirus quarantine houses out of unused shipping containers. Teachers followed the 5E Model to facilitate student engagement in the project and online design resources such as Google SketchUp, Planner 5d, and Floor Planner, were used by the students as needed to create their designs. Student projects were shared through online student presentations (via live or recorded presentations) and in some schools, written reports detailed proposed innovations. The 5E structure utilized follows.

A. Engage: To set the stage with students, teachers identified an engineering innovation currently underway related to the challenges presented by the COVID-19 pandemic (such as the U.S. example of an innovation design converting shipping containers into Quarantine Houses).

B. Explore: Students brainstormed potential needs related to the world-wide COVID-19 pandemic.

C. Explain: Students described identified need(s) and potential solution(s), verbally or in writing.

D. Elaborate: Students drew their design idea(s), either free hand or using drawing software available on their computers and/or built models with items found in their homes.

E. Evaluate: Students shared their engineering designs widely (with other students, family members, etc.) through online environments and provided each other with feedback and suggestions.

Teachers were provided with Leadership Certificates and a Student Participation Certificate template to personalize for each of their students (see Figure 1). 

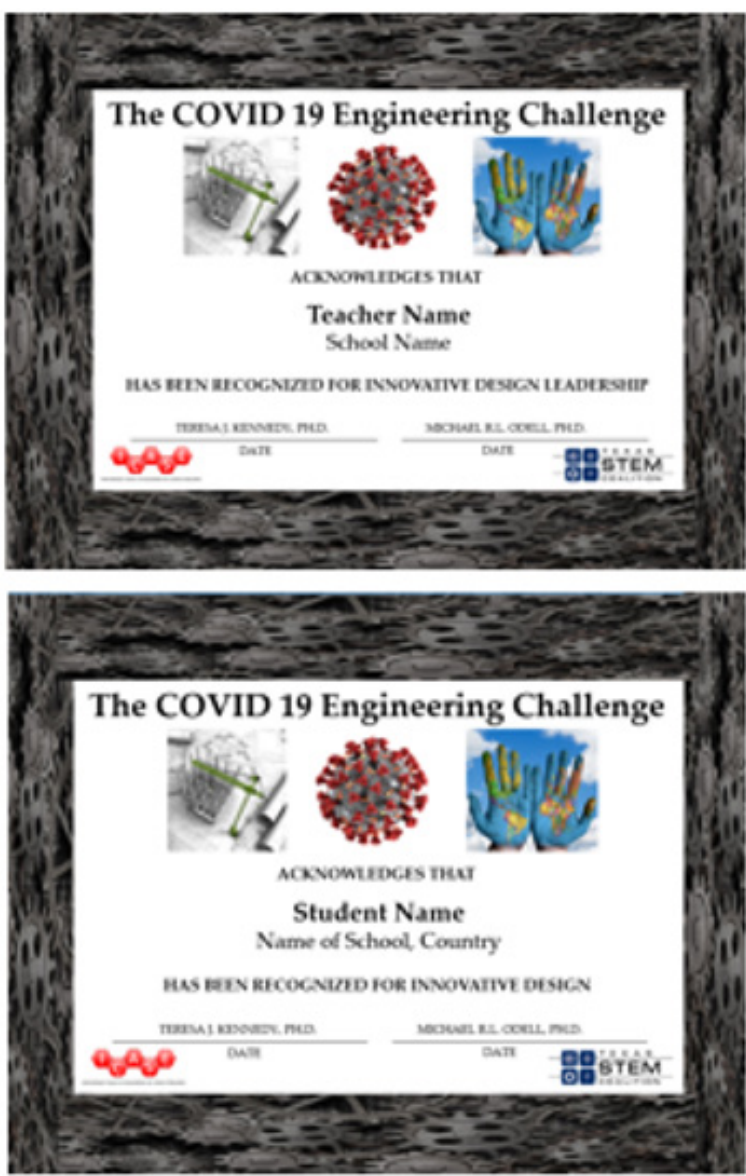

Figure 1: COVID-19 Participation Certificates.

\section{Expanding the Challenge Internationally}

The COVID-19 Engineering Design Challenge provides a natural learning experience for students in STEM classrooms as well as in language classrooms around the world. Through collaborations with the International Council of Associations for Science Education (http://www.icaseonline.net/), the teacher instructions as well as a sample student handout describing the U.S. innovation involving shipping containers transformed into quarantine houses were translated in the six United Nations (UN) languages (Arabic, Chinese, English, French, Russian and Spanish), plus Japanese, Portuguese and Turkish. Teachers internationally were encouraged to share examples highlighted into their country in response to needs related to the challenges presented by the COVID-19 pandemic or provide their students with the U.S. example of an innovation design converting shipping containers into quarantine houses.

Impact data were gathered from participating teachers after projects were completed through a simple Qualtrics survey. Survey questions included prompts to share teacher contact information, their location (country), and information about their school type. Teachers were also asked to report the subject(s) they teach, the grade level of their students, the number of participating students as well as the gender of their students. Teachers were also asked to provide the number of student projects created along with the names of the projects. If teachers were interested in sharing their students' work, they were invited to upload projects to the survey, or provide them via Google Drive or email. Finally, teachers were asked to describe how their students presented the results of their projects (whether students shared their projects through classroom presentations, online venues, etc.), and describe the audience for the presentations.

\section{Covid-19 Engineering Design Challenge Results}

Nearly 400 students from 9 countries participated in the 2020 Challenge. These students, from Argentina, China, the Dominican Republic, England, Japan, Peru, Russia, Turkey, and the U.S., ranged from primary, secondary and university environments. Almost half of the participating students were girls. Sample classroom implementation activities included online discussions and brainstorming sessions; student created PowerPoint presentations; individual and group projects that included student hand-drawn designs as well as designs created with the assistance of online technology tools; the building or constructing of models; writing community service announcements; and also detailed research reports submitted by university students.

Projects ranged from designing masks that recycle exhalation "so that you don't have to continuously smell your bad breath" to recyclable face masks to help solve the problem of single-use masks that are washing up on shorelines and littering the seabed, as well as innovative sterile mask collection bins. Other innovations included designs for temperature scanning systems to be used before entering buildings, creating city designs that included recovery communities for those infected, and designs for treadmill systems programmed to monitor your health (including COVID testing) that include virtual tours such as visiting a museum as well as tours to popular locations around the city to "keep you healthy while you can't visit the gym and for when you are tired of staying at home" (in the words of the student inventors).

In addition, many students designed technology innovations such as robots programmed to roam buildings providing hand sanitizer while also cleaning and sterilizing the floor as they move from room to room. The list of innovative ideas and projects is extensive. Examples include:
a. Face Mask factories.
b. Sterile Recycle Bins/Recycling Units for used face masks.
c. Face Masks for Fresh Breath.
d. Automated Face Mask Detection System (AFMDS). 
e. Reusable Personal Protective Equipment (PPE).

f. Drone Face Mask Detection System.

g. Recovery Communities/Houses.

h. Mobile Disinfectant Robot - roams schools and communities.

i. New Generation Restaurants (social distance proof).

j. Personal Health Monitors.

k. Distance Meter COVID Shoes.

l. Guardbox - Personal Protection Storage System.

m. Sanitization Stations.

n. Temperature Scanners for building/door entries.

o. Cleaner Gloves that are recyclable.

p. Hygienic Door handles/holders.

q. Coro-Watch (watch programed to detects the virus).

r. Teach-Robo (a robot that serves as a teacher).

s. Solar powered workstations with sanitization dispensers.

t. Antimicrobial Seat Covers for vehicles and restaurants.

u. Video conferencing programs (to facilitate learning at home).

v. Virtual treadmill programs.

w. Research papers (university student submissions).

Plans are currently underway to create a web page dedicated to sharing student projects and to organize an online student conference enabling participating students to share their innovations with one another. Due to teacher request, the Challenge has continued through 2021. Details about how to join the Challenge follow.

\section{The 2021 COVID-19 Engineering Design Challenge}

Many schools are beginning to reopen their doors and resume classes in face-to-face environments. Whether students continue to receive instruction online or return to in-person instruction, the importance of engaging in collaborative activities such as the COVID-19 Engineering Design Challenge are paramount as they provide opportunities for students from diverse locations around the world to develop potential solutions to the serious problems we all face due to the Pandemic as well as engage in international discussions. While some of these students will become scientists in the future, all of these students benefit from having the opportunity to become active global citizens. Aspiring global citizens need to develop skills related to problem-solving, decision-making, critical thinking, communication, and collaboration [5].

"The ongoing pandemic of coronavirus disease 2019 (COVID-19), the disease caused by severe acute respiratory syndrome coronavirus 2 (SARS-CoV-2), has caused unprecedented disruption of human society" [6]. The Centers for Disease Control and Prevention [7] is currently monitoring several Variants of Interests (VOI) and Variants of Concern (VOC). According to the Center for Disaster Philanthropy, "As this disease continues to spread across the world and emerge in new countries, despite the implementation of vaccines, the needs of communities and responding NGOs, governments and medical facilities are becoming clearer. As the pandemic continues into its second year, some key areas still need attention, although these vary depending upon the stage of the pandemic in a particular community" [8]

Engage your students in this timely project addressing worldwide concerns surrounding COVID-19 by empowering them to think about solutions to local and world-wide issues they have become aware of due to media updates and discussions occurring in their homes and educational environments. Students that participate in research design develop greater problem-solving skills, better understanding of research methods, and learn about career and education pathways $[9,10]$.

Join the 2021 COVID-19 ENGINEERING DESIGN CHALLENGE. For more information about how to involve your students, see https://uttyler.az1.qualtrics.com/jfe/form/SV_eXILiS0zOZ2pAnb/.

\section{References}

1. World Health Organization (WHO) (2021) Coronavirus disease (COVID-19) pandemic.

2. Worldometer (2021) Covid-19 Coronavirus Pandemic.

3. Heubeck E (2020) How Did COVID-19 Change Your Teaching, for Better or Worse? See Teachers' Responses. Education Week.

4. Internet Society (2021) 2020 Impact Report: The Internet is a Lifeline.

5. Kennedy TJ \& Sundberg CW (2020) $21^{\text {st }}$ Century Skills. In B Akpan, et al (Eds.) Science Education in Theory and Practice: An Introductory Guide to Learning Theory (Chapter 32, pp. 479-496), (eBook), Switzerland.

6. Baric RS (2020) Emergency of a Highly Fit SARS-CoV-2 Variant. N Engl J Med 383(27): 2684-2686.

7. Centers for Disease Control and Prevention (CDC) (2021) SARS-CoV-2 Variant Classifications and Definitions.

8. Center for Disaster Philanthropy (CDP) (2021) COVID 19 Coronavirus.

9. Kennedy TJ, Odell MRL (2014) Engaging Students in STEM Education. Science Education International 25(3): 246-258.

10. UNESCO (2019) What is education for sustainable development? [Web page]. United Nations Educational, Scientific and Cultural Organization. 